\title{
Origin of Native Potassium in Alonso Soil
}

\author{
Héctor M. Lugo, Juan Colom, and Rafael Pietri ${ }^{1}$
}

\section{INTRODUCTION}

Using the X-ray spectroscopic method, Jeffries et al. $(7,8)^{2}$ did not detect potassium-bearing minerals in either coarse or clay fraction of Alonso soil. Although they did not identify potassium feldspars in Alonso, they suggested the available potassium may originate from these minerals. They also found kaolin to be the only clay mineral of Alonso, notwithstanding their reported high exchange capacity for this soil.

More recent work (10) concerning the mineral composition of the coarse fraction of Alonso confirmed the findings of Jeffries et al. $(7,8)$ that potassium-bearing minerals were not found in Alonso in the sand or silt fraction; also, that a high cation exchange capacity was detected. This suggested the possibility that native potassium in Alonso could originate from a clay mineral which escaped detection by techniques employed in previous investigations.

This paper reports the identification of the minerals present in the clay fraction of Alonso with special emphasis on the mica species.

\section{MATERIALS AND METHODS}

The methods of handling soil samples and the fractionation techniques used are described elsewhere $(5,6,10)$. The clay was divided by centrifugation in two fractions corresponding to 2-0.2 $\mu$ and less than $0.2 \mu$. Both fractions were washed until free from sodium carbonate and were kept suspended as sodium saturated in distilled water.

About $50 \mathrm{mg}$. of suspended clay samples were oriented in ceramic $(9,11)$ plates and held in an aluminum-well-holder when subjected to a sequential treatment consisting of glycerol solvation and calcium saturation, potassium saturation and heat. Clay samples which were not subjected to the sequential treatment were mounted on glass slides for X-ray characterization. A Norelco unit equipped with $\mathrm{Co} \mathrm{K} \alpha$ radiation, $14^{\circ}-0.003$ inch $1 / 4^{\circ}$ slits arrangement, scanning at $2^{\circ}, 2 \theta$ per minute, was used.

Potassium was determined by flame photometry from sodium carbonate fusion (3) of clay samples.

The cation exchange capacity of the soil was determined by the ammonium acetate procedure recommended by Hanna ( $(3)$.

1 Instructor and Research Assistant, College of Agriculture and Mechanical Arts and Agricultural Experiment Station, and Professors, College of Agriculture and Mechanical Arts, Mayagüez Campus, University of Puerto Rico, Mayagüez, P.R.

2 Italic numbers in parentheses refer to Literature Cited, p. 74-5. 


\section{RESULTS AND DISCUSSION}

The results obtained during the identification of the clay fraction less than $0.2 \mu$ in size of Alonso soil, are presented in figure 1. Samples were examined initially for $\mathrm{X}$-ray diffraction as $\mathrm{Ca}$-saturated and glycerol solvated. These demonstrated two distinct basal reflections, one at about $7 \AA^{3}$ and the other at about $10 \AA$ regardless of sampling depth. A heat treatment sequence was then employed to help identify the clay minerals after replacing calcium with potassium by washing the oriented clay samples several times with a few milliliters of $0.1 \mathrm{~N} \mathrm{KCl}$ and then with distilled water. The $10 \AA$ peak basal reflection persisted up to $700^{\circ} \mathrm{C}$. With increasing temperature, the $10 \AA$ peak became better defined in terms of intensity and sharpness. It thus is clear that we are dealing here with a micaceous specie and not an expansive clay mineral. As demonstrated later, illite $^{4}$ adequately fits the clay mineral corresponding to the $10 \AA$ basal reflection observed.

The $7 \AA$ basal reflection clearly corresponds with the clay mineral kaolin. The fact that the initial $7 \AA$ peak did not shift either with glycerol solvation or heat, and that it disappeared at $550^{\circ} \mathrm{C}$., supports its definite identification as kaolin.

The X-ray patterns of the $2-0.2 \mu$ clay fractions were identical qualitatively to those of the fraction less than $0.2 \mu$. As shown in table 1, however, the intensity (counts per second) of the kaolin peak was more than double the intensity of the illite peak in the same pattern for all the depths. This indicates a corresponding kaolin to illite concentration in the coarse clay fraction of Alonso of not less than 2:1. On the other hand, the concentration of kaolin is about the same as illite in the fine clay fraction $(<0.2 \mu)$ for profile depths down to about 3 feet, while illite appears to predominate at lower profile depths. No reasonable interpretation can be offered that may explain the variation in the relative concentration of kaolin and illite without speculation. The differential movement of clay in the profile by virtue of the leaching processes, the nature and origin of the pedogenic formation, the active weathering factors and processes, and other conditions could contribute toward the observed behavior.

A noticeable feature about the total potassium composition of the fine clay fraction $(<0.2 \mu)$ is shown in table 2 . The trend in total potassium of the clay fraction closely corresponds to the trend in illite variation indicated above for the same fraction at different depths. Illite and total potassium (1.7 percent $K$ ) are rather uniform down to about 3 feet, then both increase

S One Angstrom (A) equals $10^{-8} \mathrm{~cm}$.

- The term illite has been applied loosely to a group of clay minerals with a higher water and lower potassium content than true micas. The term hydrous mica also has been used to refer to illite and other $\mathrm{K}$ bearing mixed-layer minerals $(2,4)$. 


$$
\|
$$


to a depth of 5 feet (2.2 percent $K$ ), and finally both decrease (1.7 percent $\mathrm{K})$.

The cation exchange capacity of Alonso soil, free of organic matter, was found to be $35 \mathrm{me}$. per $100 \mathrm{gm}$. of soil. This is lower than reported by Jeffries, Bonnet, and Abruna $(\gamma, 8)$.

TABLD 1.-Clay minerals distribution in the clay fraction of a typical Alonso profile

\begin{tabular}{|c|c|c|c|c|c|c|c|c|c|c|c|c|c|}
\hline \multirow{3}{*}{$\underset{\text { mineral }}{\text { Clay }}$} & \multirow{3}{*}{$\begin{array}{c}\text { Particle } \\
\text { size }\end{array}$} & \multicolumn{12}{|c|}{ Profile depth (inches) } \\
\hline & & $0-4$ & $6-10$ & $\mid 10-14$ & $17-21$ & $21-25$ & 30-34 & 34-38 & $43-47$ & $54-58$ & $58-62$ & $70-73$ & $73-76$ \\
\hline & & \multicolumn{12}{|c|}{ Counts per second of the most intensive peak } \\
\hline \multirow{3}{*}{ Kaolin } & Microns & 3 & 1 & 1 & 1 & 1 & 1 & 1 & 1 & 2 & 2 & 2 & 2 \\
\hline & $2-0.2$ & 47 & 41 & 55 & 30 & 67 & 59 & 43 & 63 & - & - & - & - \\
\hline & $<0.2$ & 45 & 26 & 30 & 46 & 30 & 31 & 32 & 28 & 24 & 33 & 38 & 22 \\
\hline \multirow{2}{*}{ Mlite } & $2-0.2$ & 17 & 15 & 20 & 14 & 16 & - & - & 25 & - & - & - & - \\
\hline & $<0.2$ & 38 & 20 & 30 & 30 & 15 & 30 & 36 & 56 & 46 & 52 & 55 & 25 \\
\hline Ratio of & $2-0.2$ & 0.36 & 0.37 & 0.37 & 0.47 & 0.24 & - & - & 0.40 & - & - & - & - \\
\hline illite/ & $<0.2$ & 0.84 & 0.77 & 1.0 & 0.66 & 0.5 & 1.0 & 1.13 & 2.0 & 1.92 & 1.57 & 1.45 & 1.14 \\
\hline
\end{tabular}

1 Samples irradiated as $\mathrm{Na}$ saturated.

2 Observations taken from $0.2 \mu$ samples that were irradiated after saturation with $\mathrm{K}$ and heated at $110^{\circ} \mathrm{C}$ for 2 hours.

TABLE 2.-Total potassium content in the clay fraction less than 0.8 microns of an Alonso profile

\begin{tabular}{c|c|c|c}
\hline Sampling depth & $\mathrm{X}$ content & Sampling depth & K content \\
\hline$I n$. & Percent & Inches & Percent \\
$0-4$ & 1.5 & $34-38$ & 1.6 \\
$6-10$ & 1.6 & $43-47$ & 2.6 \\
$10-14$ & 1.7 & $54-58$ & 2.2 \\
$17-21$ & 1.7 & $58-62$ & 2.7 \\
$21-35$ & 1.6 & $70-73$ & 1.9 \\
$30-34$ & 1.8 & $73-76$ & 1.7 \\
\hline
\end{tabular}

The total potassium content of the fine clay fraction is considered too low for muscovite, the only mica specie with an X-ray diffraction pattern closely resembling illite. ${ }^{4}$ Furthermore, the high cation exchange capacity observed for the soil mineral fraction could not be reasonably explained if muscovite was the other clay mineral besides kaolin. On the other hand, illite is known to have fairly high cation exchange capacity and relatively low potassium content. 
Previous investigations (10) did not identify the mineral source of native potassium in Alonso. However, Jeffries, Bonnet, and Abruña $(7,8)$ did not report the presence of illite in Alonso. The present investigation indicates illite to be an important clay mineral constituent and apparently the main source of native potassium in Alonso soil.

\section{SUMMARY}

Kaolin and illite were identified in the clay fraction of Alonso soil. The relative concentration of kaolin to illite in the 2.0-0.2 $\mu$ fraction was greater than double throughout the profile, while in the less than $0.2 \mu$ fraction, it was about the same for profile depths down to 3 feet. Illite seems to predominate over kaolin at lower profile depths.

The total potassium content of the clay fraction less than $0.2 \mu$ corresponded with the observed trend in illite variation.

Illite was found to be the only soil mineral source of native potassium in Alonso soil.

\section{RESUMEN}

Se identificaron los minerales caolín e ilita en la fracción arcilla del suelo Alonso. La concentración relativa del caolín sobre la ilita, en la fracción de 2 a $0.2 \mu$ fue siempre mayor de $2: 1$ a traves de todo el perfil. En la fracción fina $(<0.2 \mu)$, la razón de caolín a ilita fue alrededor de 1:1 para los primeros 3 pies de profundidad, predominando la ilita en las profundidades más bajas.

El contenido total de potasio en la fracción menor de $0.2 \mu$ correspondió bien con el patrón de variación en el contenido de ilita.

Se identificó la ilita como la única fuente mineral del potasio nativo en el suelo Alonso.

\section{LITERATURE CITED}

1. Abruña, F., and Smith, R. M., Clay mineral types and related soil properties in Puerto Rico, Soil Sci. 75: 411-20, 1953.

2. Bradley, W. F., and Grim, R. E., The X-Ray Identification and Crystal Structure of Clay Minerals, Ch. V, pp. 208-41, Mineralog. Soc., London, Eng., 1961.

3. Hanna, W. J., Chemistry of the Soil, Ch. XII, pp. 478-9 and 497-8,| Reinhold Pub. Corp., New York, N.Y., 1964.

4. Jackson, M. L., Soil Clay Mineralogy, Ch. VIII, p. 255, Univ. Press, Chapel Hill, N.C., 1964.

5. Jackson, M. L., Soil Chemical Analysis-Advanced Course, published by the author, Department of Soils, Univ. Wis., Madison, Wis., 1956.

6. Jackson, M. L., Whittig, L. D., and Pennington, R. P., Segregation procedure for the mineralogical analysis of soils, Soil Sci. Soc. Amer. Proc. (1949) 14: 77-81, 1950.

7. Jeffries, C. D., Bonnet, J. A., and Abruña, F., The constituent minerals of some soils of Puerto Rico, J. Agr. Univ. P.R. 87 (2): 114-39, 1953. 
8. Jeffries, C. D., Bonnet, J. A., and Abruña, F., Mineral characteristics of some soils of Puerto Rico, Soil Sci. Soc. Amer. Proc. 16 (3): 310-11, 1952.

9. Kinter, E. B., and Diamond, S., A new method for preparation and treatment of oriented-aggregate specimens of soil clays for $\mathrm{X}$-ray diffraction analysis, Soil Sci. 81: 111-20, 1956.

10. Lugo, H. M., Colom, J., and Pietri, R., A pualitative mineral analysis of the coarse fraction of an Alonso soil, J.Agr. Univ. P.R. 54 (1): 62-69, 1970.

11. Whittig, L. D., X-Ray diffraction techniques for mineral identification and mineralogical composition. In Methods of Soil Analysis, pt. I, Ch. IXL, pp. 686-87, Amer. Soc. Agron. Inc., Madison, Wis., 1965. 